\title{
A DISGUISED PENTHEUS HIDING IN THE BRITISH MUSEUM?
}

\author{
OLIVER TAPLIN \\ Magdalen College, Oxford
}

\begin{abstract}
RESUMO: Durante os últimos vinte e cinco anos, duas correntes opostas têm dominado a discussão sobre a relação entre as narrativas mitológicas das pinturas vasculares e as da tragédia. De um lado, há os que vêem as pinturas como dependentes das obras literárias; do outro lado, os que argumentam, de modo a mostrar que a tradição pictórica se faz inteiramente evidente por si, sem necessitar de qualquer referência a qualquer obra literária. Este artigo analisa alguns casos, em que, todavia, tal fenômeno parece ser mais complexo, inseparável dos papéis desempenhados, tanto pelos vasos pintados quanto pelas peças encenadas, no conjunto da vida do público de ambos.
\end{abstract}

PALAVRAS-CHAVE: tragédia; Eurípides; pintura vascular.

The complex inter-relations between the mythological narratives in vasepainting and those in tragedy are potentially a fascinating subject. And during the last twenty-five years much important new and highly relevant material has been first published (RVAp Supp ii). But during this same period the whole subject has become crushed, bedevilled, and almost paralysed between two opposing 'schools', both of them driven by the old battle for superiority between art and literature, rather than by the likely realities of cultural history. On the one hand there are those who regard the paintings as inspired by or dependent upon works of literature, even as 'illustrations' of them. This attitude is to be found in, for example, many entries in Webster and Trendall (1971), and in some though by no means all of the articles in LIMC. On the other hand there are those who argue that the artistic tradition is fully self-explanatory with no need of any reference to any literature (Moret, 1975); and/or that in the newly literate world of the fourth century the viewers of vases would not have known the texts of the plays (Giuliani, 1995, 
1996, 2003). At present the tide of opinion is running in favour of this side, and thus against any significant connection between the vase paintings and the plays. ${ }^{1}$

Caught in the crossfire between these two embattled positions, which are held with great passion, few scholars have been strong enough to see that neither is simply right; that the whole phenomenon is more complex, and is inextricable from the part played both by painted pottery and by the theatre in the whole lives of those who were the public for these pots and these plays. ${ }^{2}$ They have insisted that the social function of the vases and of the theatre must be taken fully into account; and that the signals, which are present - or indeed are absent - within the vase paintings, are of vital importance. A classic case of this, the subject of Green (1999), is the figure of the anonymous little old man, conventionally known as the paidagogos. ${ }^{3}$ Even though there may be some cases, especially in later fourth century 'rape' scenes, such as those of Ganymede and Europa, where there may not have been an associated theatrical version, Green has shown convincingly that this figure is prima facie and in most cases a signal of a theatrical narrative that has been transmuted into a painted narrative.

Just as some signals, such as the little old man, or the painted archway representing a cave or rock, point to a theatrical affinity and should be given proper notice, conversely scholars - and especially those of a literary predisposition - must respect signals that do not point to the theatre, or at least not to any play that we know. Take one example: the Lucanian "nestoris" in the British Museum, which is familiar as an "illustration" to accompany Sophocles' Antigone (LCS, p.102, n. 339; Webster, Trendall, 1971, v. III, 2, 4). Green has never, so far as I know, accepted this connection, presumably because the ruler sitting on the throne is clearly and conspicuously wearing an oriental headdress. While it is not out of the question that Creon was thus portrayed in some performances, there is no reason inside or outside Sophocles' play to support this speculation. This, and the youthfulness and unsoldierly demeanor of the two spear-carriers probably have to

1 See for example the lively, if often flawed, case made in Small (2003), favourably reviewed by Snodgrass (2003).

2 Outstanding among the independents have been Dick Green, and the much-lamented Margot Schmidt.

3 Even though not all of these old men are male child-carers, as is clear from, for example, the shepherd in Green (1999) n. 2 (Melanippe) and the old former shepherd from Corinth in n. 50 (Oedipus). 
outweigh the portrayal of the central woman as looking down at the ground, even though that appealingly evokes Antigone lines 441-2 in the minds of lovers of Sophocles. ${ }^{4}$

Those scouring the vase-paintings for a picture to connect with Euripides' Bacchae are even more obviously frustrated by being turned away by negative signals. There are known some ten Attic pictures and some eleven Apulian depicting Pentheus out among the Bacchants, the former mainly showing him in the process of being dismembered and the latter showing him still intact but in danger. ${ }^{5}$ There is, however, a major signal which rules out any significant connection with the Euripides play (quite apart form the chronological priority of all but one of the Attic paintings): this is that Pentheus is always (or almost always) ${ }^{6}$ portrayed as clearly male - often indeed his manhood is made obvious in a display of 'heroic nudity'. In the great majority of cases Pentheus is also armed with his sword or with two spears. The open masculinity and the military equipment are both in direct contradiction of Euripides' version, where Dionysus dissuades Pentheus from

4 One hesitation before finally dissociating this painting from Antigone may the similarity of the relatively neglected early Apulian hydria, Taranto 134905, which is 1/18 in RVAp. This too has a woman (stockier and more regal looking) standing between two youthful spear-carriers in front of an older authority-figure, though in this case the woman is turned away from him. The most peculiar feature of this composition is that the authorityfigure is painted standing underneath the handle of the hydria, making him rather isolated and almost 'trapped' - in a way that might not be inappropriate to Sophocles' Creon. Despite the similarities between the two vases there is still the crucial difference that he does not wear an oriental headdress. I should add that the LIMC Antigone article by I. Krauskopf includes the BM picture (n. 12) without hesitation, but firmly rules out the Taranto hydria (n. 22 on p. 824).

5 To those in the LIMC article on Pentheus by J. Bazant and G. Berger-Doer may be added another typical Apulian fragment, which is number 54 in Padgett and others (1993); it was included as Paestan by Trendall in RVP, p. 253, n. 1003A, but later reclassified by him as Apulian.

6 An exception, if it is an exception, is the Apulian krater, Lecce 638, which is n. 3 in LIMC (for some reason this is not included in Trendall's RVAp). This painting is dominated by two Bacchants with swords, but there is a figure, apparently male, sitting to the left, fully clothed and with the branch of a tree propped over his shoulder. According to the LIMC article he is wearing a sword, and it is claimed that this is Pentheus represented as hiding among foliage, as in Euripides' Bacchae. But, the pose looks to me more like the typical pose of, for example, Apollo, with the laurel over his shoulder - in this case, then, Dionysus? 
setting out with a military force, and prevails on him to go in female disguise as a maenad. It has been well argued by Jenny March (1989) that the allusions scattered through the play to the use of military force evoke what must have been a usual version - or even perhaps the only pre-Euripidean version - which had Pentheus setting off to the mountain openly and armed. Euripides uses these allusions to emphasise the centrality of his departure from this in sending Pentheus disguised in female garb.

All this, then, confirms that 'it would be a brave person who would see any direct link with the staging of Euripides' Bacchae' (Green, 1995, p. 113)..$^{7}$ This does, however, raise an interesting question: how might a vase-painter attempt to portray a man dressed in women's clothing, while still keeping within the convention that serious 'tragic' vase-painting does not explicitly expose its relation to the theatre? ${ }^{8}$ It is open for a 'comic' scene to show an actor with a male mask and male leggings wearing a female dress that covers his stage-phallus: that is what we have in the now well-known 'Wurzburg Telephos'. Alternatively the painter may depict a dress that is so transparent that the stage-phallus can be shown as visible underneath: this is what we have in the 'S.Agata Antigone'. ${ }^{9}$ Such clearly 'metatheatrical' or 'meta-iconographic' signals are not available to the painter of the serious scene. Would it be possible at all, then, to show that an apparent maenad was really to be recognized as an impostor, a man in disguise?

A possible answer to this puzzle might be 'boots'. Many of the male characters in fourth-century mythological narratives on vase paintings, including those which may be more or less plausibly claimed to be related to tragedy, conspicuously wear high fancy boots, some of them laced, some with ornate turned- over tops. In some of the vases, indeed, especially from the earlier part of the century, the hero wears little else except for his boots! Now it has to be granted that there are plenty of vases from the fifth century as well as the fourth century where men wear boots, yet where there is no good reason for claiming the painting to be connected with a tragedy, ie boots are not in themselves a signal pointing towards drama (unlike

7 "Brave" seems to be a euphemism for "foolhardy"!

8 This was clearly and convincingly demonstrated by Green (1991) - though this did not stop it being misunderstood by Small (2003, p. 68-71).

9 This is figure 21.22 in Taplin (1993), discussed on p. 84-88 in association with the British Museum 'Antigone' painting discussed above. As will have been gathered, I am no longer inclined to connect that with Antigone. 
the paidagogos - see above). On the other hand, high and ornate boots were very much part of the standard tragic outfit, as may be clearly documented from such famous monuments as The Pronomos Vase and The Wurzburg Actor, and as is now freshly demonstrated by the figure of the tragic Aigisthos in the 'Choregoi' vase. ${ }^{10}$ It is clear that the majority of men in mythological vase-paintings, whether or not they are believed to be 'tragedy-related', wear ornate boots - although there are numerous exceptions. And, contrarywise, the majority of female figures do not wear boots. While I cannot claim to have conducted a thorough survey, it is evident that females rarely wear fancy boots unless they are portrayed as travelling or as hunting. Thus, for example, Artemis or Furies and related figures (such as Lyssa) wear conspicuous boots, no doubt to suggest the relentlessness of their pursuit. Maenads, on the other hand, dance over the mountains in bare feet. This, like unbound hair, marks their release from conventional shackles, as is made explicit at Bacchae 862-5: "Shall I ever in the all-night dances set my white foot in bacchic revelry, tossing my throat to the dewy air...like a fawn...when it escapes...?" (Richard Seaford's literal translation; Seaford, 1996, p. 113). ${ }^{11}$ Of all the many Maenads in the pictures illustrating the LIMC article on Pentheus, they are all, so far as I can see, bare-footed, with a single exception (RVAp 2/21). ${ }^{12}$ Pentheus on the other hand usually, though not invariably, wears boots, even when he is wearing little else.

This is the juncture at which to introduce a maenad picture that is not in the LIMC article on Pentheus (plate 1). This British Museum F133, a mid fourthcentury dish (phiale), the work of an undistinguished artist identified by Trendall as close the Thyrsus Painter, who, although Apulian in style, seems to have worked for at least part of his career at Paestum (RVAp 10/190, p. 281, pl. 91, 3-4; p. 274). This picture is usually described as 'Three Maenads in Bacchic Orgy'. ${ }^{13}$ There is, however, something wrong with this orgy: the two outer maenads seem to be shown as attacking the third one in the middle; and this middle maenad is apparently using the thyrsus as a means of defence. Furthermore, while the outer two have

\footnotetext{
10 Now in the Getty Museum as 96.AE.29.

11 The reference to white feet means bare feet, cf. a similar phrase at Euripides' Kyklops 72.

12 The exception is n. 67, a fragment of an early Apulian Hydria from Taranto (Taranto 12566), which shows a Bacchant with a sword and wearing boots, along with Dionysus in a stag-drawn chariot. It remains uncertain whether or not the picture included Pentheus (or his head at least).

13 Thus catalogued by Walters (1896).
} 
the usual long dresses and bare feet, the middle maenad's clothing is only kneelength (emphasised by the decorated hem), revealing high boots with some kind of flaps. Are these boots a signal that the central maenad is to be detected as a man in disguise? At first glance there may seem to be a suggestion of breasts; but on a closer look these are clearly folds in the clothing, and quite different from conspicuous breasts of the other two. The great A.D. Trendall's sharp eye evidently did not see the folds as signs of gender, since he comments on the picture: 'The central figure may well be intended to represent Pentheus dressed as a maenad, since the other two figures are clearly attacking.' He did not, however, record this shrewd suggestion in the Index to RVAp; and it has not so far as I know been made anywhere else by him or any other commentator. If Trendall was right, this Pentheus does not display his maleness and does not have any military weapons; he is fully rigged out as a maenad, with fawn skin and thyrsos and long hair. Only the boots give him away.

So I suggest that we may have here a painting which would evoke in the viewer who has the play in mind the Euripidean version of the story. It is not - of course - an exactly accurate representation, let alone an 'illustration' of the Euripidean text. There is no reason why a narrative painting has to correspond in every detail with a text or with a performance in order to evoke it for the viewer and to be informed by it. The excessive claims of the old 'philological' school has led in reaction to over-rigid exclusions of any literary connection on the grounds that not every detail fits. There are touches here that do not match the Euridean text: for example, in Euripides, Pentheus wears a headband (929), and his dress comes down to his ankles (935-8). In the play he is reported as spying on the maenads from the top of a pine tree, where he has been miraculously seated by Dionysus (1063 ff). The Bacchants pelt him in order to try and get him down; in the end (1103ff) they tear the tree up by the roots; Pentheus falls to the ground and the maenads set upon him with their bare hands. There is even a reference to a dismembered part of Pentheus' body wearing a shoe (line 1134, arbulai - not a boot). While much of this is different from the British Museum picture, I propose that it is not so different as to contradict the invitation to the viewer to think of Euripides' Bacchae. Such issues of judgement have to be faced by those who resist the simplification of either of the dominant 'schools': what points towards the association, what points away from it, and which way does the balance more plausibly tip?

A further invitation to recall the Bacchae may well be the large tree which stands close to the central maenad. Its association with her - or him - is emphasized 
by the upright thyrsos and tambourine which separate it from the left-hand maenad. What is this tree doing there at all? It is interesting that the LIMC article reveals that large trees are to be found in some later representations in the scene from the Roman period, but that only four of the fifth and fourth century representations have any kind of foliage, and in all of the others it is much smaller than in this painting, simply suggestive of an open air-setting. Lastly, it is also worth noting that the left-hand maenad has replaced her thyrsos with a branch ripped from the tree: this may connect with line 1098 of the Bacchae, where the maenads are reported as pelting Pentheus with branches of the tree, as well as other missiles.

The case made for an interaction between this painting and Euripides' play will probably satisfy neither of the highly polarized camps in the debate over tragedy and vase painting. While it will not appeal to those who deny any perceptual connection between the paintings and literature, this picture has no good claims, on the other hand, to be a representation, let alone an illustration of Euripides. If it does invite association with Euripides, it does so with several departures from the text in detail. In other words, it is no more than an evocation. But, the configuration does, I suggest, give out some indicative signals to the viewer.

\section{ReferênCias Bibliográficas}

BERGMANN, B.; KONDOlEON, C. (ed.). The Art of Ancient Spectacle. New Haven: 1999.

GIULIANI, L. Tragik, Trauer und Trost: Bildervasen für eine apulische Totenfeier. Berlin: 1995.

. Rhesus between dream and death: on the relation of image to literature in

Apulian vase-painting. BICS. n. 41, p. 71-86, 1996.

. Bild und Mythos. Geschichte der Bilderzählung in der griechischen Kunst. München: 2003.

GREEN, J. R. On seeing and depicting the theatre in Classical Athens. GRBS. n. 32, p. 15-50, 1991.

. Theatre Production: 1987-1995. Lustrum. n. 37, p. 7-202, 1995.

. Tragedy and the Specatcle of the Mind: Messenger Speeches, Actors, narrative, and Audience I magination in Fourth-Century BCE Vase-Painting. In: BERGMANN, B.; KONDOLEON, C. (ed.). The Art of Ancient Spectacle. New Haven: 1999. p. 37-63. 
LCS $=$ TRENDALL, A. D. The red-figured vases of Lucania, Campania and Sicily. Oxford: 1967.

LIMC = ACKERMANN, H. C.; GISLER, J.-R.; KAHIL, L. (ed.). Lexicon Iconographicum Mythologiae Classicae. Zürich: 1981-2002.

MARCH, J. Euripides' Bacchai: a recosideration in the light of the vase paintings. BICS. n. 36, p. 33-65, 1989.

MORET, J. M. L' Ilioupersis dans la céramique italiote: les mythes et leur expression figurée au IVe siècle, Rome: 1975.

PADGETT, J. M. Vase-painting in Italy: red-figure and related works in the Museum of Fine Arts. Boston: 1993.

RVAp = TRENDALL, A. D.; CAMBITOGLOU, A. The red-figured vases of Apulia. Oxford: 1982.

RVAp, Supp ii = TRENDALL, A. D.; CAMBITOGLOU. Second supplement to the red-figured vases of Apulia. london: 1991-1992.

RVP $=$ TRENDALL, A. D. The red-figured vases of Paestum. London: 1987.

SEAFORD, R. (ed). Euripides' Bacchae. Warminster: 1996.

SMALL, J. P. The parallel worlds of classical art and text. Cambridge: 2003.

SNODGRASS, A. Review of Small. TLS. n. 5244, p. 9, 2003.

TAPLIN, O. Comic angels: and other approaches to Greek drama through vase-paintings. Oxford: 1993.

WALTERS, H. B. Catalogue of vases in the British Museum. v. IV. London: 1896.

WEBSTER, T. B. L.; TRENDALL, A. D. Illustrations of Greek drama. London: 1971.

\section{INFORME}

A primeira versão deste artigo foi publicada em Mediterranian Archaeology, Sidney: The University of Sidney, n. 17, 2004, Festscrift em homenagem a J. R. Green, e foi apresentada no colóquio internacional "Novas abordagens em ciências da Antigüidade" (FFLCH/USP e MAE/USP, 2004). O autor é grato pelas observações e comentários feitos pelos participantes do colóquio. 
TAPLIN, O. A disguised Pentheus hiding in the British Museum?

ABSTRACT: During the last twenty-five years, two opposing trends have dominated over the debate about the relationship between mythological narratives in vase-painting and those in tragedy. On the one hand, there are those who regard the paintings as dependent upon works of literature; on the other hand, there are those who argue that the artistic tradition is fully self-explanatory with no need of any reference to any literature. This paper analyzes some cases, in which the whole phenomenon seems to be more complex, and to be inextricable from the part played both by painted pottery and by the theatre in the whole lives of those who were the public for these pots and these plays.

KEYWORDS: tragedy; Euripides; vase-painting. 